\title{
Interocean Exchange of Thermocline Water
}

\author{
ARNOLD L. GoRdon \\ Lamont-Doherty Geological Observatory of Columbia University, Palisades, New York
}

\begin{abstract}
Formation of North Atlantic Deep Water (NADW) represents a transfer of upper layer water to abyssal depths at a rate of 15 to $20 \times 10^{6} \mathrm{~m}^{3} / \mathrm{s}$. NADW spreads throughout the Atlantic Ocean and is exported to the Indian and Pacific Oceans by the Antarctic Circumpolar Current and deep western boundary currents. Naturally, there must be a compensating flow of upper layer water toward the northern North Atlantic to feed NADW production. It is proposed that this return flow is accomplished primarily within the ocean's warm water thermocline layer. In this way the main thermoclines of the ocean are linked as they participate in a thermohaline-driven global scale circulation cell associated with NADW formation. The path of the return flow of warm water is as follows: Pacific to Indian flow within the Indonesian Seas, advection across the Indian Ocean in the $10^{\circ}-15^{\circ} \mathrm{S}$ latitude belt, southward transfer in the Mozambique Channel, entry into the South Atlantic by a branch of the Agulhas Current that does not complete the retroflection pattern, northward advection within the subtropical gyre of the South Atlantic (which on balance with the southward flux of colder North Atlantic Deep Water supports the northward oceanic heat flux characteristic of the South Atlantic), and cross-equatorial flow into the western North Atlantic. The magnitude of the return flow increases along its path as more NADW is incorporated into the upper layer of the ocean. Additionally, the water mass characteristics of the return flow are gradually altered by regional ocean-atmosphere interaction and mixing processes. Within the Indonesian seas there is evidence of strong vertical mixing across the thermocline. The cold water route, Pacific to Atlantic transport of Subantarctic water within the Drake Passage, is of secondary importance, amounting to perhaps $25 \%$ of the warm water route transport. The continuity or vigor of the warm water route is vulnerable to change not only as the thermohaline forcing in the northern North Atlantic varies but also as the larger-scale wind-driven criculation factors vary. The interocean links within the Indonesian seas and at the Agulhas retroflection may be particularly responsive to such variability. Changes in the warn? water route continuity may in turn influence formation characteristics of NADW.
\end{abstract}

\section{INTRODUCTION}

Warm salty water spreads into the northern North Atlantic, where it is cooled primarily by evaporation. Ironically, this is a consequence of its anomalously high temperature relative to the atmosphere [Warren, 1983]. This in turn maintains relatively high salinity and density despite an abundance of precipitation. The cooled salty water sinks to the deep ocean, marking the formation of North Atlantic Deep Water (NADW) [Warren, 1981; Killworth, 1983]. The NADW from the two northern sites (Labrador Sea and the Greenland SeaNorwegian Sea overflow), with a mean temperature and salinity of approximately $2^{\circ} \mathrm{C}$ and $34.93 \%$ (the northern component defined by Broecker et al., [1976] and Broecker and Peng [1982]), spreads to the south within the deep western boundary current, being joined by the saltier outflow from the Mediterranean Sea. The NADW water mass influences most of the global ocean [Reid and Lynn, 1971]. Warren [1981], reviewing the estimates of NADW formation rate, arrives at a number of $14 \mathrm{~Sv}\left(1 \mathrm{~Sv}=10^{6} \mathrm{~m}^{3} / \mathrm{s}\right)$. Broecker [1979], using radiocarbon data, suggests a formation rate of greater than $20 \mathrm{~Sv}$. The two northern components account for over $90 \%$ of the NADW volume flux.

The process of NADW formation is self-perpetuating in that as the surface layer water sinks and is exported southward within the deep layer, more upper layer water is drawn into the northern North Atlantic. This in turn drives the high evaporation rates continuing the NADW formation process. Whether a random event initialized the circulation or whether it is a response to the changing distribution of the land masses and associated large-scale circulation remains a tantalizing problem in oceanography. The thermohaline circulation pat-

Copyright 1986 by the American Geophysical Union.

Paper number 6C0064.

0148-0227/86/006C-0064\$05.00 tern in the meridional plane associated with the NADW formation is one of a negative estuary [Stommel, 1956; Reid, 1961; Worthington, 1981; Gordon and Piola, 1983]: upper layer water moves to the north, while deeper water moves to the south. This pattern is clearly seen in the results of the inverse solutions for the Atlantic Ocean using the International Geophysical Year (IGY) set of zonal hydrographic sections [Roemmich, 1980, 1983; Fu, 1981; Wunsch, 1984; Roemmich and Wunsch, 1985]. Comparison of the IGY data with recent data sets indicates the suspected stability of the thermohaline circulation, though the distribution of the transport within the various density strata does vary [Roemmich and Wunsch 1985].

The choice for the separation between the two layers varies, but only slightly, among authors. Gordon and Piola [1983], noting that the salty characteristic of NADW is incorporated into the Antarctic circumpolar belt below the $\sigma_{0}$ density of 27.6 [Georgi, 1981], place water less dense than that value within the upper layer (this includes the thermocline and intermediate water). The density interval from $\sigma_{0}$ of 27.7 to $\sigma_{2}$ of 36.82 divides the upper and lower layers in the inverse method approaches [Roemmich, 180; Roemmich and Wunsch, 1985]. McCartney and Talley's [1984] separation between northward and southward flow falls near $4^{\circ} \mathrm{C}$, which coincides more or less with the $27.7 \sigma_{0}$.

Broecker and Peng [1982] in their discussion of the upper layer leed for NADW point out that the upper layer water must have about the same nutrient concentrations as NADW, since there is no significant source or sink of nutrients in the North Atlantic. In their Table 7-2 the nutrient concentrations for the various components of NADW are listed. Characteristic $\mathrm{PO}_{4}, \mathrm{NO}_{3}$, and $\mathrm{SiO}_{2}$ concentrations are 1,15 , and 12 $\mathrm{mol} / \mathrm{kg}$, respectively. Inspection of the GEOSECS data [Bainbridge, 1981] indicates that within the central North Atlantic these values are associated with temperatures between $11^{\circ}$ and $13^{\circ} \mathrm{C}$ and salinity of approximately $35.55 \%$, corresponding to 
a $\sigma_{0}$ of 27.0. Thus the feed water is derived from within the main thermocline, well above the Antarctic Intermediate Water (AAIW) layer.

The magnitude of the thermohaline circulation for the Atlantic Ocean has been estimated by various means. The inverse method approach of Roemmich and Wunsch [1985] yields for the IGY and 1981 transatlantic sections at $24^{\circ}$ and $36^{\circ} \mathrm{N}$ an average of $17 \mathrm{~Sv}$ for the northward flow of upper layer water (surface component of $11.3 \mathrm{~Sv}$ and intermediate water component of $5.8 \mathrm{~Sv}$ ), which balances the southward flowing deep water (19.9 Sv, $2.9 \mathrm{~Sv}$ of which is returning Antarctic Bottom Water). This estimate is close to the 15- to 16-Sv values given by Roemmich [1980] and Hall and Bryden [1982]. These estimates do not take into account the Pacific to Atlantic transfer of about $1 \mathrm{~Sv}$ in the Bering Strait [Coachman et al., 1975], so the southward deep flow is expected to be slightly above the northward upper layer flow. Box models based on temperature and salinity yield similar results. Gordon and Piola [1983] find that gradual increase in salinity of the northward flowing Atlantic Ocean upper layer water can be justified with the Baumgartner and Reichel [1975] estimates of fresh water exchange with the atmosphere if the magnitude of the thermohaline circulation cell is near $20 \mathrm{~Sv}$. McCartney and Talley [1984] investigate the thermal field, finding southward flow across $50^{\circ} \mathrm{N}$ of $14.1 \mathrm{~Sv}$ of cold water. Their feed of upper layer water into the NADW formation region is about $11.5^{\circ} \mathrm{C}$, similar to the temperature horizon necessary to meet the nutrient requirements.

As NADW spreads into the South Atlantic and then eastward with the Antarctic Circumpolar Current into the Indian and Pacific oceans, the negative estuary circulation pattern is expected to extend out of the North Atlantic into the rest of the world ocean [see Broecker and Peng, 1982, Figures 1-13; Piola and Gordon, 1984]. The objective of this paper is to explore the general form of this global scale thermohaline circulation cell and demonstrate support for the hypothesis that upper layer return flow is accomplished primarily within the main thermoclines of the ocean.

The NADW upwells within the world ocean, returning water to the upper layer within the Antarctic region and into the thermocline. Antarctic and thermocline upwelling may be coupled in that deep water upwelling around Antarctica contributes to the formation of Antarctic Intermediate Water, which then spreads below the thermocline and upwells into the thermocline. There are two routes by which the upper layer water can return to the Atlantic Ocean, though they are not mutually exclusive: the cold water route within the Drake Passage, in which AAIW and Subantarctic Mode Water (SAMW) pass into the South Atlantic [Georgi, 1979; Piola and Georgl, 1982; McCartney, 1977], and the warm water route, in which Indian Ocean thermocline water is introduced to the South Atlantic south of Africa (Gordon, 1985). It is proposed that the warm water route is the more important.

\section{WARM WATER ROUTE}

As was mentioned above, most of the northward flow within the upper layer in the North Atlantic resides in the warmer water above the intermediate stratum [Broecker and Peng, 1982; Roemmich and Wunsch, 1985]. A simple demonstration that this is also the case in the South Atlantic can be made on the basis of the equatorward oceanic heat flux characteristic of the South Atlantic. Hastenrath [1982] determines that $69 \times 10^{13} \mathrm{~W}$ pass to the north across $30^{\circ} \mathrm{S}$. Invoking the concept that the wind-driven Brazil Current within the thermoclıne is weakened by the thermohaline-driven circu- lation pattern [Stommel, 1957] as some South Atlantic thermocline water is transferred into the North Atlantic, it is possible to determine the mean temperature of the northward moving upper layer water across $30^{\circ} \mathrm{S}$.

The mass and heat flux equation across $30^{\circ} \mathrm{S}$ are

Mass

$$
V_{i}=\left[V_{b z}+V_{n}\right]-V_{b s}
$$

Heat

$$
V_{1} T_{t}=\left[V_{b z} T_{b z}+V_{n} T_{n}\right]+Q_{f}
$$

where $V_{1}$ is the mass flux of the northward moving water, with a temperature of $T_{i}$, within the interior of the South Atlantic; $V_{b z}$ is the mass flux of the Brazil Current within the upper layer, with a transport averaged temperature of $T_{b z} ; V_{n}$ is the mass flux of NADW across $30^{\circ} \mathrm{S}$, with a temperature of $T_{n} ; V_{b s}$ is the mass flux of water through the Bering Strait; and $Q_{f}$ is the northward oceanic heat flux across $30^{\circ} \mathrm{S}$.

A production rate of $20 \mathrm{~Sv}$ for NADW, with uniform upwelling north of $30^{\circ} \mathrm{S}$, yields $16 \mathrm{~Sv}$ for $V_{n} ; T_{n}$ is taken as $2^{\circ} \mathrm{C}$. $V_{b s}$ is taken as 1.5 Sv [Coachman et al., 1979]. The transport of the Brazil Current in the upper layer increases from approximately $6.5 \mathrm{~Sv}$ across $19^{\circ}-23^{\circ} \mathrm{S}$ to $17.1 \mathrm{~Sv}$ across $38^{\circ} \mathrm{S}$ [Gordon and Greengrove, 1986]. An intermediate value of $10 \mathrm{~Sv}$ is taken for $V_{b z}$. The combined transport of the Brazil Current and NADW flow across $30^{\circ} \mathrm{S}$ is $26 \mathrm{~Sv}$, which approximately balances the Sverdrup interior transport across $30^{\circ} \mathrm{S}$, given as 30 Sv by Hellerman and Rosenstein [1983]. The value used for $T_{b z}$ is $18^{\circ} \mathrm{C}$, as was determined from the distribution of the meridional component of the volume transport in temperaturesalinity space given by Miranda and Castro Filho [1981] for the Brazil Current at $19^{\circ} \mathrm{S}$. Using the Hastenrath [1982] $Q_{f}$, $50 \%$ of $Q_{f}$, and $5 \%$ of $Q_{f}$, equations ( $\left.1 a\right)$ and $(1 b)$ are solved, resulting in a $T_{i}$ of $15.4^{\circ} \mathrm{C}, 12.0^{\circ} \mathrm{C}$ and $9^{\circ} \mathrm{C}$, respectively (Figure 1).

The warmest water in the Drake Passage is about $8^{\circ} \mathrm{C}$ [Gordon and Molinelli, 1982], and the volumetric mode of the AAIW/SAMW in the southwest Atlantic, which can be traced into the South Atlantic, is $3.5^{\circ} \mathrm{C}$ [Georgi, 1979]. Thus even in the extreme case in which the Hastenrath heat flux value is an order of magnitude too high, the cold water route cannot be the sole supplier of upper layer return to the NADW production region. Assuming that the Hastenrath $Q_{f}$ is roughly correct, the bulk of the upper layer return flow must reside within the thermocline. The only source for such water south of $30^{\circ} \mathrm{S}$ is the Indian Ocean thermocline water within the Agulhas Current.

The proposed global scale warm water route associated with thermohaline-driven circulation cell is as follows (Figures $2 a, 2 b$, and $2 c$ ): The upwelling NADW returns water to the thermocline which was lost during production of NADW. The primary site of upwelling is the southern ocean, where the upwelled NADW eventually flows below the thermocline and enters the thermocline as AAIW. The thermocline water is returned to the North Atlantic by the following route:

1. The NADW introduced into the Pacific Ocean is transferred as North Pacific Central (thermocline) Water to the Indian Ocean through the Indonesian seas.

2. The Pacific water crosses the Indian Ocean in the $10^{\circ}-$ $15^{\circ} \mathrm{S}$ latitude belt, incorporating the saltier Indian Ocean thermocline water.

3. The mix of Pacific Ocean and Indian Ocean water passes southward within the Mozambique Channel, supplying a small component of the Agulhas Current transport. 


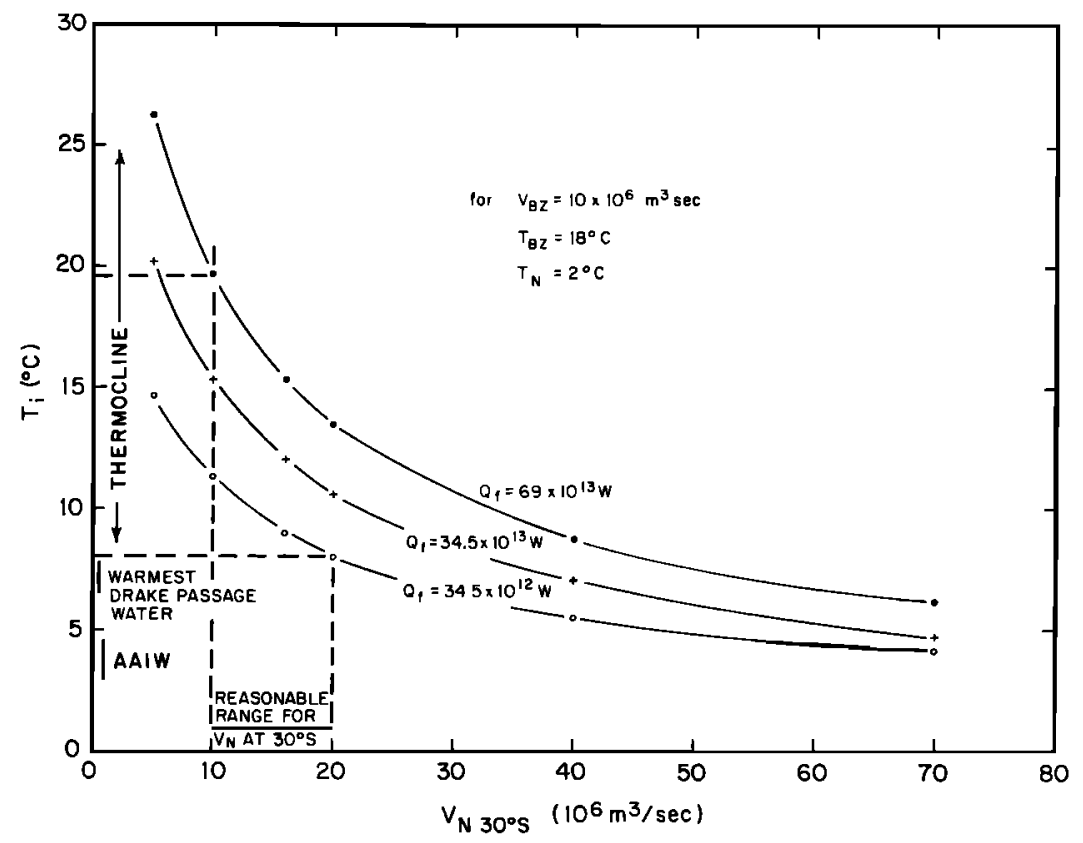

Fig. 1. Relationship of the temperature of the water flowing to the north across $30^{\circ} \mathrm{S}\left(T_{i}\right.$, see equation (1)) as is required to balance the component of NADW advected southward across $30^{\circ} \mathrm{S}\left(V_{n}\right.$, see equation (1)). The relation is given for three values of $Q_{f}$ (the northward heat flux across $30^{\circ} \mathrm{S}$ ): the value given by Hastenrath [1982], half of that value, and $5 \%$ of that value. See equations $(1 a)$ and $(1 b)$ for explanation of other values.

4. A branch of the Agulhas Current flows into the South Atlantic and does not participate in the Agulhas retroflection, which returns most of the Agulhas water to the Indian Ocean.

5. The warm water passes northward with the South Atlantic subtropical gyre, crossing the equator to enter the upper layer of the North Atlantic.

Assuming a 20-Sv production rate of NADW with uniform upwelling into the world ocean (thus the Pacific receives 50\% of the deep water, with the Atlantic and Indian oceans splitting the rest equally [Piola and Gordon, 1984]) and assuming that the cold water route is insignificant, it is possible to place some numbers on the magnitude of the warm water route (Figure 2a). The assumption of uniform upwelling (introduced by Stommel and Arons [1960]) may not be strictly adhered to. For example, if a larger proportion of NADW upwells in the Atlantic, the transport values given for the Pacific-Indian and Indian-Atlantic transfer would be reduced. Hence these numbers are not overly significant, since the assumptions are not likely to be strictly followed, but they do provide some "ball park" estimates which can be compared with other, independent determinations.

The following section attempts to show supporting evidence for key links of the proposed interocean warm water route.

\section{Evidence For The Warm Water Route}

\section{Indonesian Through Flow}

The most comprehensive physical oceanographic work on the Indonesian seas is that of Wyrtki $[1957,1961]$. On the basis of water mass analysis he shows that Pacific water spreads into the Indian Ocean down to depths of $1000 \mathrm{~m}$. Replacement of the water filling the deep basin of the Banda Sea by sill overflow is an active leature within the Indonesian seas. The displaced deep water is responsible for the lowsalinity Banda Intermediate Water of the Indian Ocean [Rochford, 1966]. Above the 1000-m flow, Wyrtki traces some eastward transfer, primarily by lateral mixing, of the Indian $\mathrm{O}_{2}$ minimum layer into the Banda Sea. At depths shallower than approximately $500 \mathrm{~m}$, flow is more substantial and is directed into the Indian Ocean. This water, derived from the Mindanao Current, contains subtropical salinity maximum and intermediate salinity minimum water masses of the North Pacific. "Thus in all layers with the exception of that of the oxygen minimum, movements from the Pacific to the Indian Ocean predominate" (page 114 of the Wyrtki [1961] study).

Water mass analysis using the gridded Levitus [1982] data set (Figures 3, 4, and 5), supports the results of Wyrtki [1961]: The water within the Banda Sea thermocline $\left(10^{\circ}-20^{\circ} \mathrm{C}\right.$ layer $)$ is similar to that of the North Pacific Central (thermocline) Water, with only minor requirements for additional fresh water (Figure 4). The Banda Sea thermocline water enters the Indian Ocean primarily in the passages adjacent to Timor island (Figure 3). The low-salinity thermocline within the eastern tropical Indian Ocean (Figure 3) is similar to the Banda Sea/North Pacific thermocline water (Figure 5). It spreads within the South Equatorial Current across the full width of the Indian Ocean, as will be discussed below. Furthermore, it is noted that within the $10^{\circ}-20^{\circ} \mathrm{C}$ layer of the Indonesian seas, the vertical mixing (cross-isopycnal) coefficient must be large (greater than $3 \times 10^{-4} \mathrm{~m}^{2} / \mathrm{s}$ ) to account for the modification of the North Pacific thermocline temperature-salinity structure. The subtropical $S$ maximum of the North Pacific thermocline is destroyed as an isohaline thermocline forms in the Banda Sea (Figure 4). The thermohaline structure is not conducive to salt finger activity. The mixing is more likely a product of interaction of the circulation with the irregular topography of the region.

Intense vertical mixing implies substantial downward heat flux within the Banda Sea thermocline. The vertical temperature gradient is $10^{\circ} \mathrm{C}$ in $150 \mathrm{~m}$ (area 23 on Plate 205 of Wyrtki [1971]); a vertical mixing coefficient of $4 \times 10^{-4} \mathrm{~m}^{2} / \mathrm{s}$ yields downward heat flux of $110 \mathrm{~W} / \mathrm{m}^{2}$. The atmosphere to ocean heat exchange for the region is approximately $90 \mathrm{~W} / \mathrm{m}^{2}$ [Talley, 1984]. Thus as the water flows through the Indonesian seas, the upper layers of the thermocline would remain at the same temperature or perhaps cool slightly, even though 


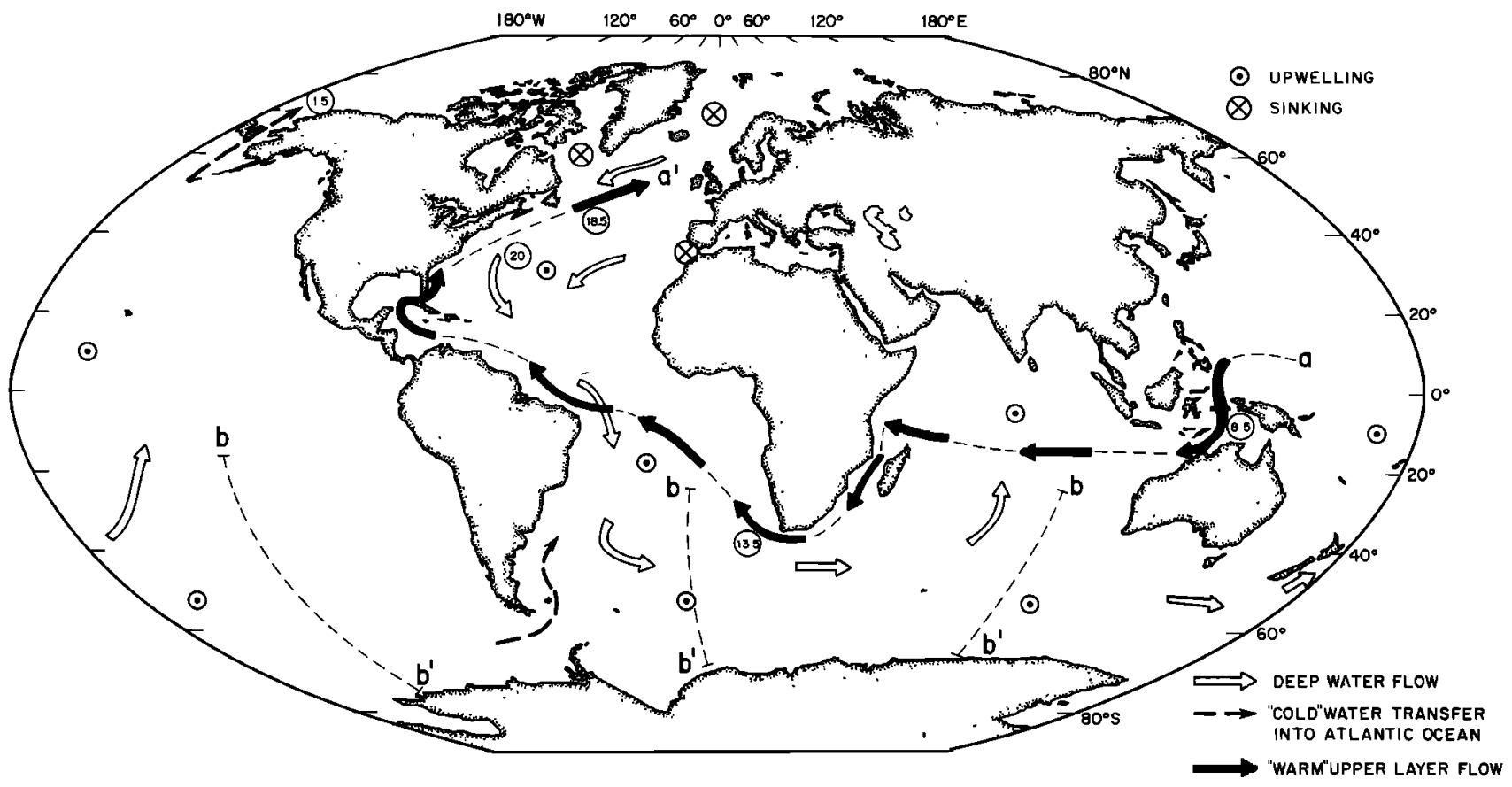

Fig. 2a. Global structure of the thermohaline circulation cell associated with NADW production. The warm water route, shown by the solid arrows, marks the proposed path for return of upper layer water to the northern North Atlantic as is required to maintain continuity with the formation and export of NADW. The circled values are volume flux in $10^{6}$ $\mathrm{m}^{3} / \mathrm{s}$ which are expected for uniform upwelling of NADW with a production rate of $20 \times 10^{6} \mathrm{~m}^{3} / \mathrm{s}$. These values assume that the return within the cold water route, via the Drake Passage, is of minor significance.

the atmosphere to ocean heat flux is large, while the lower thermocline would warm. This effect probably accounts for the decrease of surface water temperature from over $28^{\circ} \mathrm{C}$ in the western tropical Pacific to less than $28^{\circ} \mathrm{C}$ in the eastern tropical Indian Ocean receiving the through flow (for example, see the surface temperature maps of Pickard and Emery [1982]) despite strong atmospheric heating of the ocean.

Wyrtki [1971] shows that the nutrient concentrations in the Banda Sea on the $25.0 \sigma_{0}$ surface (near the $18^{\circ} \mathrm{C}$ isotherm at $150 \mathrm{~m}$ ) are $1.0,15$, and $23 \mathrm{~mol} / \mathrm{kg}$ for $\mathrm{PO}_{4}, \mathrm{NO}_{3}$, and $\mathrm{SiO}_{2}$, respectively. Closer to the base of the thermocline, at the 26.6- $\sigma_{0}$ surface (near the $10^{\circ} \mathrm{C}$ isotherm at $350 \mathrm{~m}$ ), nutrients are higher by somewhat less than a factor of $2: 1.8,30$, and 35 $\mathrm{mol} / \mathrm{kg}$ for $\mathrm{PO}_{4}, \mathrm{NO}_{3}$, and $\mathrm{SiO}_{2}$, respectively. Within the $\mathrm{Pa}$ cific Ocean's North Equatorial Current, which is the source for the Mindanao Current [Tsuchiya, 1968] feeding the transfer to the Indian Ocean, there is a strong nutrient-cline across the $15^{\circ}$ to $20^{\circ} \mathrm{C}$ layer [Wyrtki and Kilonsky, 1984]. Values of
$0.5,5$, and $5 \mathrm{~mol} / \mathrm{kg}$ near $18^{\circ} \mathrm{C}$ yield to $2.0,25,30 \mathrm{~mol} / \mathrm{kg}$ near the $10^{\circ} \mathrm{C}$ isotherm for $\mathrm{PO}_{4}, \mathrm{NO}_{3}$, and $\mathrm{SiO}_{2}$, respectively, a factor of 5 increase. The breakdown of the nutrient-cline and elevated nutrient concentrations in the upper layer of the Banda Sea thermocline is likely to be a consequence of the large vertical mixing coefficient within the Indonesian seas. The high nutrient levels characteristic of the Indian Ocean thermocline north of $15^{\circ} \mathrm{S}$ may be derived at least in part from the vigorous mixing within the Indonesian seas.

The North Pacific origin for the water flow into the Indian Ocean [Wyrtki, 1961] suggests that the NADW contribution to the North Pacific thermocline is the chief supplier for this link of the warm water route. The NADW entering the more saline South Pacific thermocline may add some water to the flow through, (associated with equatorial upwelling and advection) along the north coast of New Guinea (Figure 3), but it appears to have a secondary impact on the Banda Sea salinity. This leads to the question, where does most of the

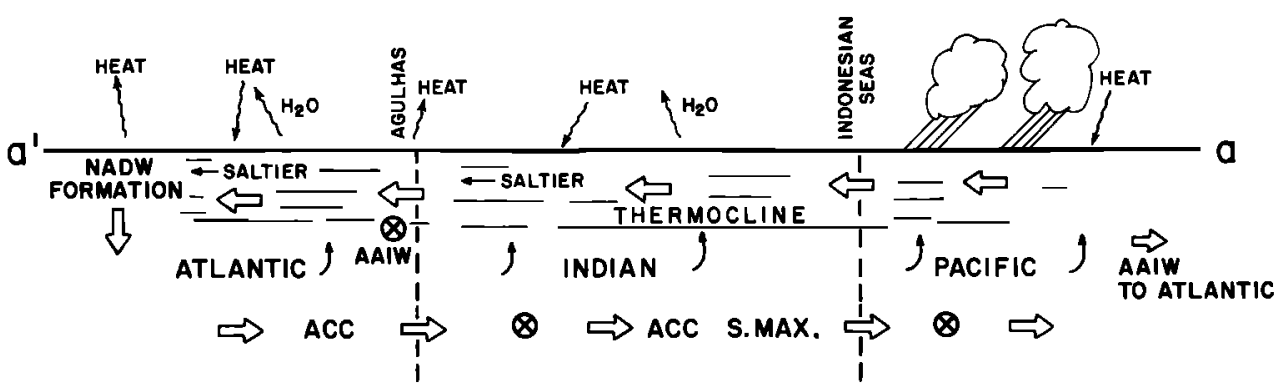

Fig. $2 b$. Schematic representation of the thermohaline circulation cell associated with NADW production and the warm water route along line $a-a^{\prime}$ shown in Figure $2 a$. The upper layer water within the main thermocline begins its passage to the North Atlantic in the Pacific as low-salinity water. It enters the Indian Ocean via the Indonesian seas, where its salinity and volume flux increase by excess evaporation and further upwelling of NADW, respectively. The thermocline water enters the Atlantic south of Africa and spreads to the northern Atlantic, continuing to increase in salinity and volume flux. 


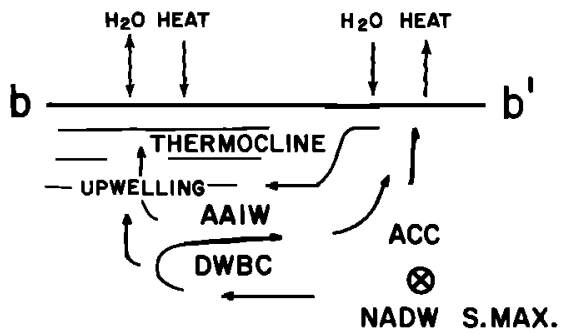

Fig. 2c. Schematic representation of the paths followed as NADW upwells, becoming incorporated into the thermocline, along line $b-b$ ' shown in Figure $2 a$. The main upwelling is expected to occur in the Antarctic region, with eventual transfer to the thermocline as Antarctic Intermediate Water.

NADW entering the South Pacific thermocline go? This is not the main topic of this paper, but it is suggested that it may feed the cold water route via the Drake Passage. Under the assumption of uniform NADW upwelling, this would account for a maximum of $25 \%$ of the total return flow into the North Atlantic Ocean.

There has been some work addressing the magnitude of the Pacific to Indian Ocean transfer. Wyrtki [1961] determines the current velocity from differences in dynamic heights. South of Timor Island (Timor Sea) a single station pair indicates a flux of 6.4 Sv. This flow is accomplished within the upper 300 $\mathrm{m}$. However, in his summary of transports for the upper 150 to $200 \mathrm{~m}$ (his Table 12, p. 136), the resultant flow from the Indonesian waters to the Indian Ocean ranges from a low of 1 $\mathrm{Sv}$ in the December to February period to $2.5 \mathrm{~Sv}$ in August, with an annual average of $1.7 \mathrm{~Sv}$.

Recently there have been a rash of estimates (based on a variety of methods) of the Pacific to Indian transfer of water, all of which are larger than Wyrtki's estimate (Table 1). The average of all estimates is $\mathbf{9 . 2} \mathrm{Sv}$ into the Indian Ocean.

Clearly, there is agreement that the water flow is toward the Indian Ocean, but there is a wide range of estimates as to its magnitude. The value proposed in this paper $(8.5 \mathrm{~Sv}$, Figure $2 a)$ is close to the average estimate. The values would be halved to about 4 Sv if the NADW entering the South Pacific thermocline returns to the Atlantic by way of the Drake Passage. However, there is likely to be additional Pacific to Indian transport which balances eastward transfer of (cooled) thermocline water south of Australia. The value presented in Figure $2 a$ represents only that component involved in the global scale NADW-thermocline circulation cell.

\section{Trans-Indian Ocean}

The low-salinity thermocline within the westward flowing South Equatorial Current in the $10^{\circ}$ to $15^{\circ} \mathrm{S}$ latitude belt of the Indian Ocean (Figure 3) has temperature-salinity characteristics similar to those of Banda Sea water emerging from the Timor Sea region (Figures 5 and 6; also see $W y r t k i$ [1971], Plates 223, 231, and 237 for salinity on isopycnal surfaces within the thermocline and Plates 364 to 369 and 394 for dynamic topography), attesting to its Pacific origin. The characteristic of this feature stands in sharp contrast to the more saline thermocline of the south Indian Ocean and Arabian Sea; a lesser contrast is seen with the Bay of Bengal. Inspection of the evolution of the temperature-salinity relation in the downstream direction shows a steady increase of salinity above the $10^{\circ} \mathrm{C}$ isotherm (Figures 3 and 6). The salinity increases by approximately $0.5 \%$ throughout the thermocline before reaching the Somali Basin in the western Indian Ocean. It is likely that the salt is introduced by lateral (isopycnal) mixing with the neighboring thermoclines. The salinity levels within the neighboring thermoclines are maintained by the regional excess of evaporation over precipitation [Baumgartner and Reichel, 1975]. In addition, NADW incorporated into the Indian Ocean thermocline, via the AAIW route or directly (Figure 2c), would be expected to swell the transport of the warm water return flow during transit of the Indian Ocean.

The nutrient concentrations within the Indian Ocean thermocline north of $15^{\circ} \mathrm{S}$ are significantly above those within the south Indian Ocean thermocline [Spencer et al., 1982]. As was mentioned above, similar levels are observed in the Banda Sea, and it is suspected that the intense vertical mixing within the Indonesian seas may, at least in part, be responsible. This may also be true for the more or less isohaline thermocline of the northern Indian Ocean. Thus it is possible that the Pacific

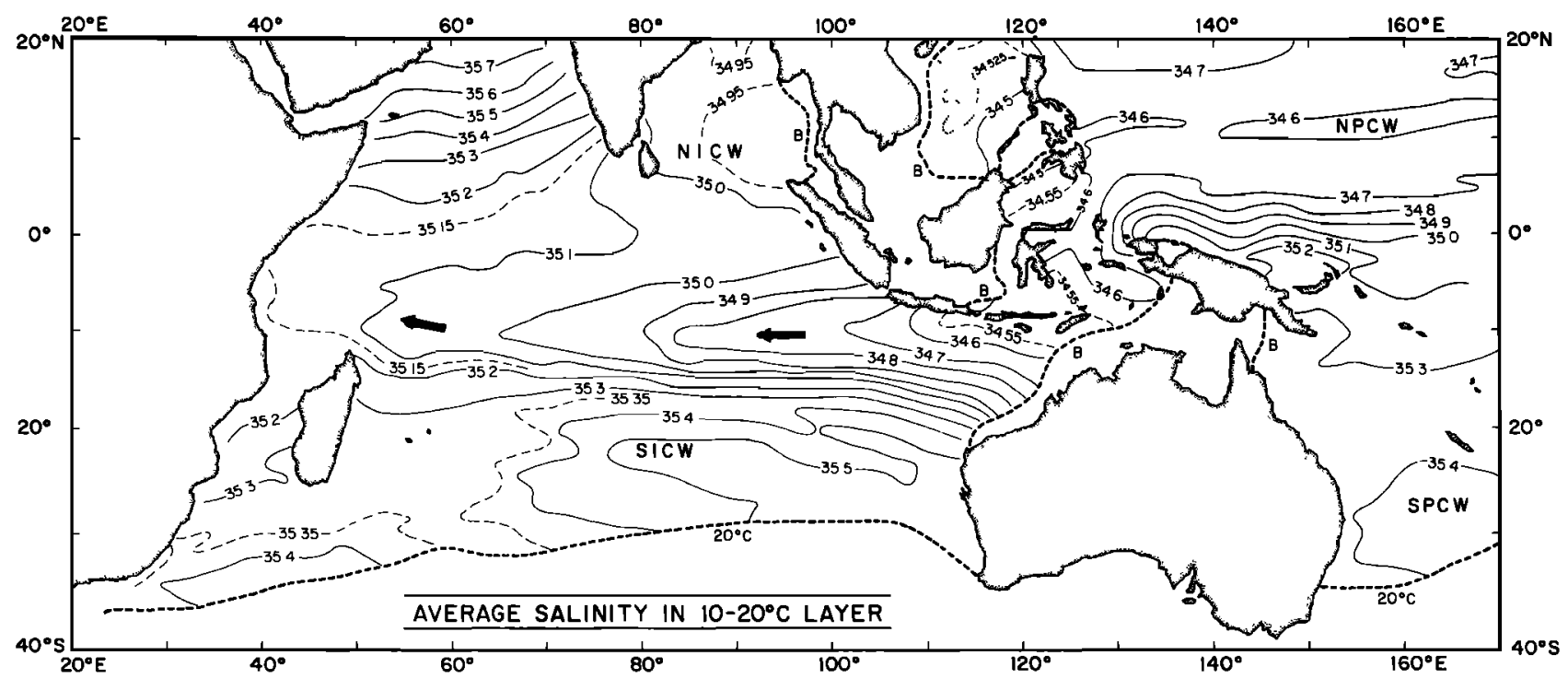

Fig. 3. Average salinity in the $10^{\circ}$ to $20^{\circ} \mathrm{C}$ layer of the main thermocline, prepared from the Levitus [1982] data set. Intersections of the $20^{\circ} \mathrm{C}$ isotherm and the surface and of the $10^{\circ} \mathrm{C}$ isotherm and the sea floor are shown as thick dashed lines. NPCW, SPCW, NICW, and SICW are the central or thermocline water of the North Pacific, South Pacific, north Indian, and south Indian oceans, respectively. 


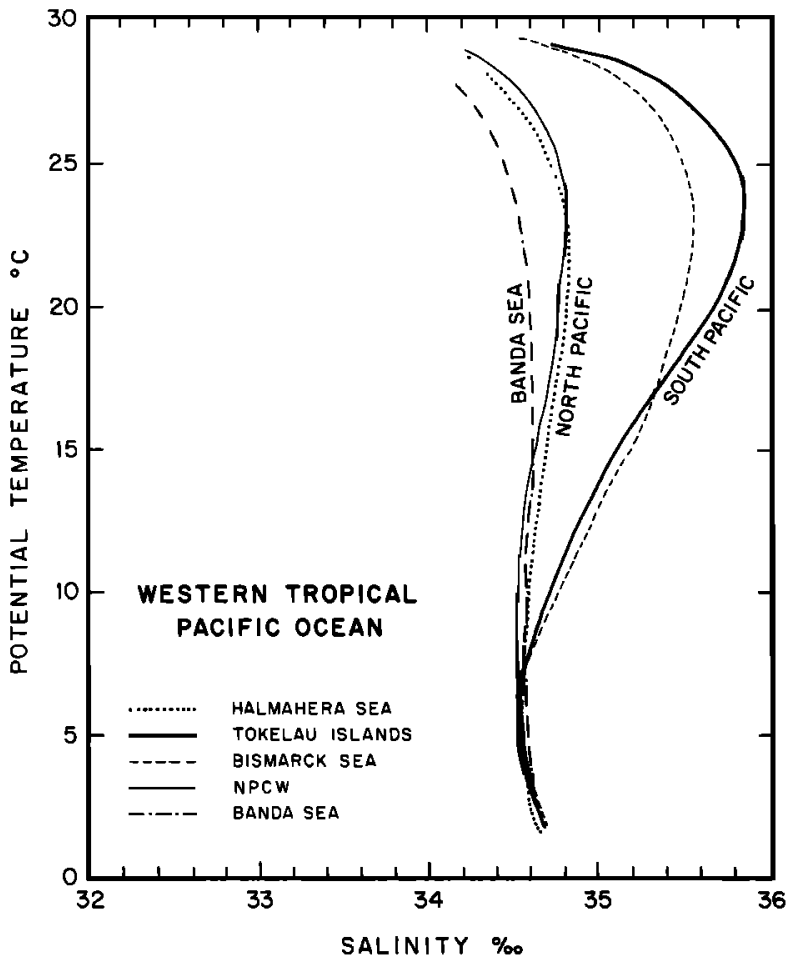

Fig. 4. The potential temperature-salinity relationship for various seas or regions of the western tropical Pacific Ocean and Banda Sea, from the Levitus data set. The Banda Sea curve is similar to the thermocline characteristics of the North Pacific. It is possible to "produce" the Banda Sea curve from the North Pacific curve with strong vertical (cross-isopycnal) mixing and with the addition of slight amount of fresh water (of the order of $10 \mathrm{~cm}$ ). To produce the Banda Sea curve from South Pacific thermocline water requires far more vigorous mixing and the addition of nearly $10 \mathrm{~m}$ of fresh water, a condition believed improbably for realistic residence time of through flow water within the Indonesian seas.

inflow to the Indian Ocean is an important determiner of the thermocline water properties of the northern Indian Ocean and that it feeds the southward flux via the Mozambique Channel.

\section{Mozambique Channel}

The low-salinity thermocline characteristic of the Somali Basin can be traced to spread southward within the Mozambique Channel (Figure 7; also see Wyrtki [1971, Plates 223, 231, and 237]), but the signal is weak. Saetre and da Silva [1984] conclude that the circulation within the Mozambique Channel is dominated by anticyclonic gyres with only minor through flow. They call into question the older concept that the Mozambique Channel is the main supplier of the Agulhas Current. Rather, the bulk of the Agulhas Current seems to be associated with a strong anticyclonic gyre situated west of $45^{\circ} \mathrm{E}$ within the $30^{\circ}$ to $40^{\circ} \mathrm{S}$ belt of the Indian Ocean [Wyrtki, 1971, Plate 394]; however, some input from the Mozambique Channel and East Madagascar Current is likely [Wyrtki, 1971, Plates 364 to 369 ; Harris, 1972; Lutjeharms, 1976]. Harris [1972] estimates 10-Sv flows poleward through the Mozambique Channel. Fu's [1986] inverse method solution for six hydrographic sections in the Indian Ocean indicates southward transport in the Mozambique Channel of $6 \mathrm{~Sv}$, similar to his value for the Indonesian sea through flow (Table $1)$.

A hydrographic section adjacent to Durban obtained from the R/V Meiring Naude in October 1983 [Grundlingh, 1986; A.

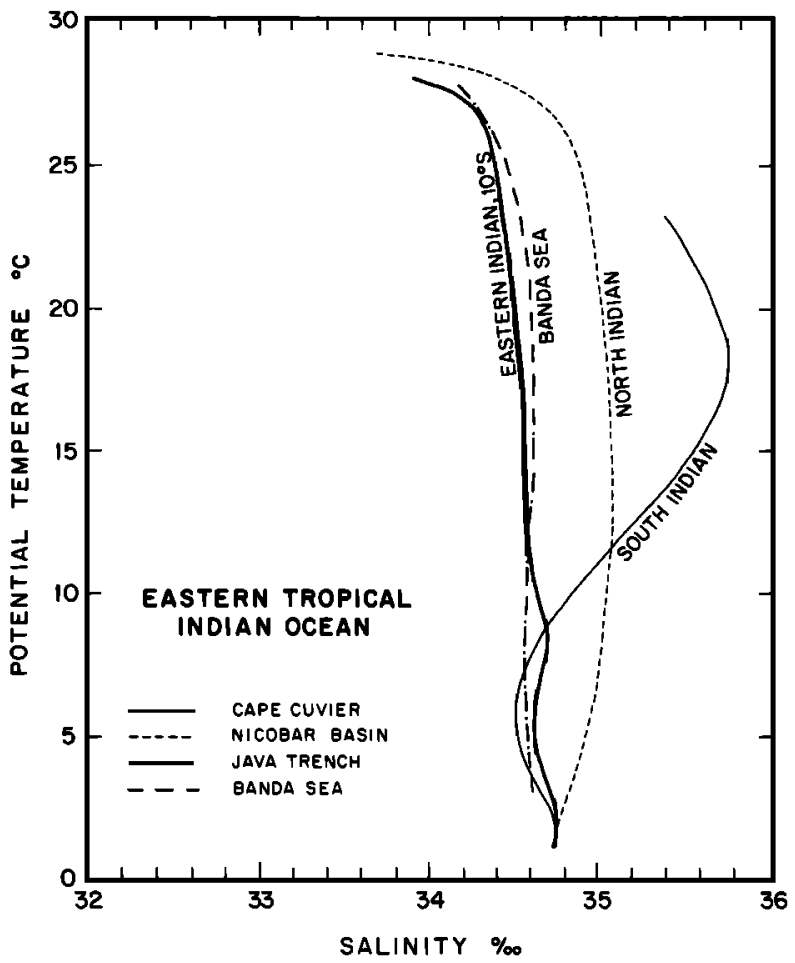

Fig. 5. The potential temperature-salinity relationship for various seas or regions of the eastern tropical Indian Ocean from the Levitus data set. The water within the low-salinity thermocline along the $10^{\circ}$ to $15^{\circ} \mathrm{S}$ latitude belt (see Figure 3) is similar to that of the Banda Sea and is much more saline than that of the Indian Ocean to the south and north. This similarity supports the Banda Sea (North Pacific) origin of the low-salinity feature.

L. Gordon et al., manuscript in preparation, 1986] shows the inshore segment of the Agulhas Current is marked by reduced salinity within the thermocline at temperatures above $14^{\circ} \mathrm{C}$. The temperature-salinity relationship of the feature is nearly identical to that found in the Mozambique Channel, while the temperaure-salinity curve, 10 to $20 \mathrm{~km}$ further offshore matches that of the East Madagascar Current (Figure 7). This low-salinity thermocline feature along the inshore side of the

TABLE 1. Estimates of Pacific to Indian Ocean Transport Within the Indonesian Seas

\begin{tabular}{|c|c|c|}
\hline Who & What, Sv & How \\
\hline Wyrtki [1961] & 1.7 & dynamic calculations \\
\hline $\operatorname{Cox}[1975]$ & 18 & $\begin{array}{l}\text { general circulation } \\
\text { model (experiment } \\
\text { III); pressure } \\
\text { around Australia } \\
\text { equated to zero }\end{array}$ \\
\hline Godfrey and Golding [1981] & 10 & $\begin{array}{l}\text { mass transport in } \\
\text { the eastern Indian } \\
\text { Ocean }\end{array}$ \\
\hline Piola and Gordon [1984] & 14 & $\begin{array}{l}\text { freshwater box } \\
\text { model of the } \\
\text { Pacific and } \\
\text { Indian oceans }\end{array}$ \\
\hline Fine $[1985]$ & 5.1 & $\begin{array}{l}\text { tritium box model } \\
\text { (upper } 300 \mathrm{~m} \text { ) }\end{array}$ \\
\hline$F u[1986]$ & 6.6 & $\begin{array}{l}\text { inverse method } \\
\text { applied to six } \\
\text { Indian Ocean } \\
\text { sections }\end{array}$ \\
\hline
\end{tabular}

$1 \mathrm{~Sv}=10^{6} \mathrm{~m}^{3} / \mathrm{s}$ 
Agulhas Current is also seen in the 1973 Meiring Naude section off Durban used by Pearce [1977]. Thus the water mass composition indicates that the low-salinity Mozambique Channel input is confined to the inshore segment of the Agulhas (this is also seen in the Wyrtki [1971] plates). Sections of the 1983 Meiring Naude data set further to the south, and those of the R/V Knorr obtained in November and December 1983 in the Agulhas retroflection [Gordon, 1985; Huber et al., 1985; A. L. Gordon et al., manuscript in preparation, 1986] reveal that the Mozambique Channel signature can be traced to the south, but it becomes more diffuse as mixing with the more saline offshore components occurs.

Grundlingh [1984] reports the presence of an intrusion of Red Sea water of $5^{\circ} \mathrm{C}$ near $1400 \mathrm{~m}$ in the southern end of the Mozambique Channel. He concludes that the Mozambique Channel closure below the $27.5-\sigma_{t}$ surface as suggested by Lutjeharms [1976] is not complete.

It is suggested that the Mozambique Channel water, while a minor component of the Agulhas Current volume flux, does inject specific water mass characteristics derived from the Somali Basin into the Agulhas, and it is feasible that the level of transport required by the warm water route (Figure $2 a$ ) can be supported.

\section{Agulhas Leakage}

The Agulhas Current is the most energetic western boundary current of the southern hemisphere; volume transport estimates vary from $44 \mathrm{~Sv}$ [Toole and Raymer, 1985] to the range $62-75 \mathrm{~Sv}$ [Grundlingh, 1980] as the current passes adjacent to Durban, with $80 \%$ occurring in the upper $1000 \mathrm{~m}$ [Grundlingh, 1980].

The Agulhas Current turns westward as its path follows the

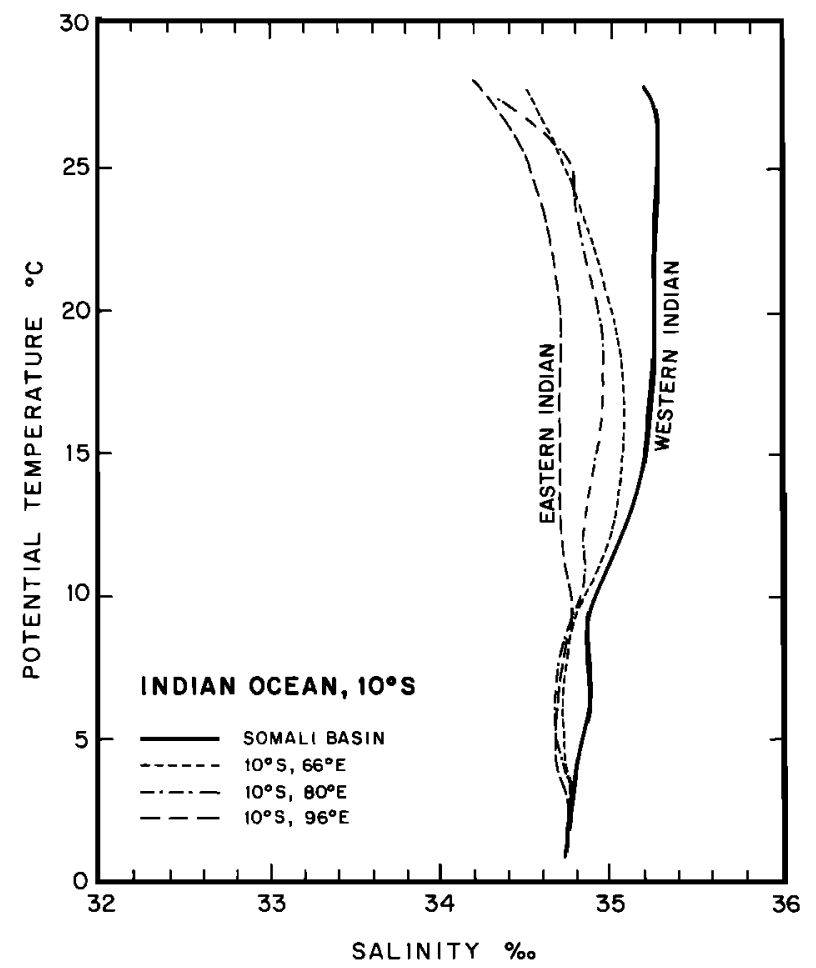

Fig. 6. The potential temperature-salinity relationship for the low-salinity thermocline along the $10^{\circ}$ to $15^{\circ} \mathrm{S}$ latitude belt of the Indian Ocean (see Figure 3), from the Levitus data set. The isohaline character is maintained as the salinity increases by approximately $0.5 \%$ on proceeding westward with the South Equatorial Current from the eastern Indian Ocean to the western margin, within the Somali Basin.

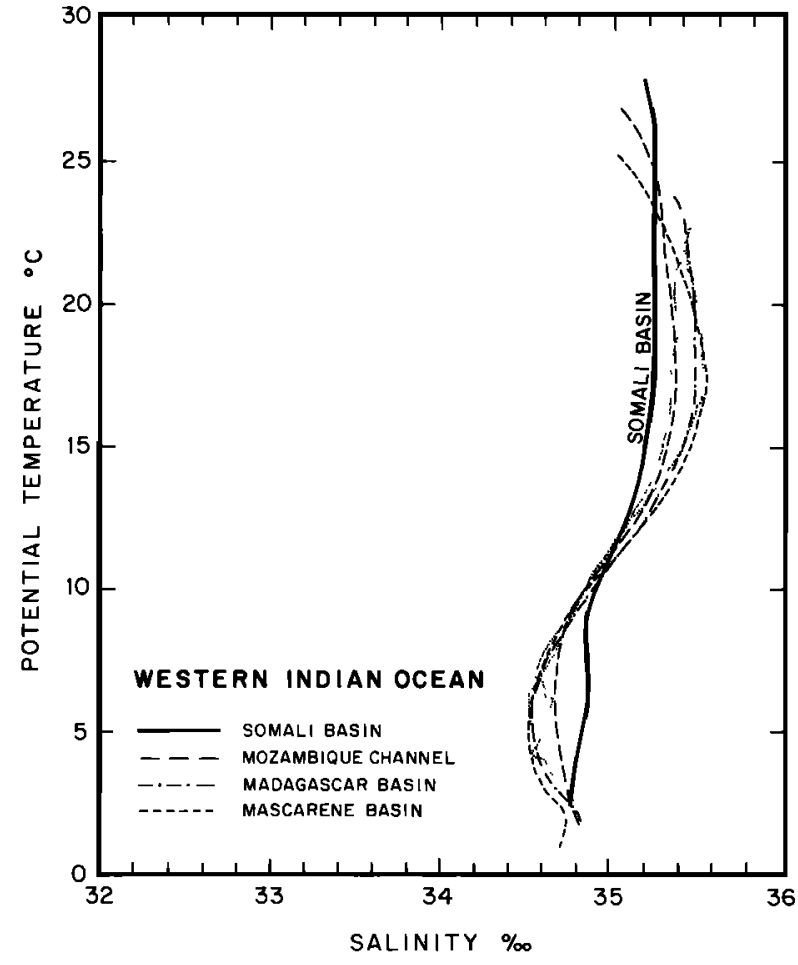

Fig. 7. The potential temperature-salinity relationship along the western South Indian Ocean, from the Levitus data set. The Madagascar Basin represents the East Madagascar Current regime, and the Mascarene Basin represents the anticyclonic circulation gyre of the southwest Indian Ocean. The two fine dotted lines are from stations within the Agulhas Current (data were obtained from the R/V Meiring Naude in October 1983) adjacent to Durban. The station from the inshore segment of the current is nearly identical to the water within the Mozambique Channel, whereas the characteristics of the outer segment of the Agulhas Current are closer to those of the East Madagascar Current, suggesting that the Mozambique input is confined to the inshore side of the Agulhas Current.

southern terminus of the African continent, separating from the margin near $22^{\circ} \mathrm{E}$. After separation it executes an abrupt anticyclonic turn to the east in what is referred to as the Agulhas retroflection [Bang, 1970]. The dynamics of the retroflection are addressed by de Ruijter [1982] and $O u$ and de Ruijter [1985]. Not all of the Agulhas water participates in the retroflection. Using the Knorr November-December 1983 hydrographic data set, Gordon [1985] on the basis of water mass characteristics and geostrophic flow shows the presence of isolated rings of Agulhas water west of the retroflection (also see Duncan [1968] and Olson and Evans [1985]). Between the ring centers and the African mainland, is an Agulhas Current branch, carrying $14 \mathrm{~Sv}$, directed into the South Atlantic Ocean. The 1983 situation is remarkably similar to that found in Mach 1969, when a synoptic data set indicates that $5 \mathrm{~Sv}$ of Agulhas water enters the South Atlantic [Harris and Van Foreest, 1978], and to the pattern shown by Dietrich [1935]. Model studies also depict linkage between the subtropical gyres of the South Atlantic and Indian oceans [Veronis, 1973; de Ruijter and Boudra, 1985].

The Mozambique Channel input to the Agulhas system carries the high-nutrient characteristic of the Indian Ocean north of $15^{\circ} \mathrm{S}$. This is seen in density surface maps of Wyrtki [1971] as nutrient rich water spreads poleward along the western boundary. The hydrographic data obtained within the Agulhas Current axis south of Africa from aboard the Knorr in November and December 1983 [Huber et al., 1985] reveal nutrient levels similar to the level required to match the feed 
water within the North Atlantic [Broecker and Peng, 1982]. The potential temperature nutrient relation for the southeast Atlantic thermocline is quite similiar to that within the western and central South Atlantic (GEOSECS data of Bainbridge [1981]). This may be due to strong exchange between the South Atlantic and Indian Oceans, so "fresh" introduction of Indian water into the South Atlantic may not contrast strongly with the background. Introduction of high silica concentrations from the Indian Ocean water into the South Atlantic on the 27.1- $\sigma_{0}$ surface is inferred by Kawase and Sarmiento [1985].

\section{Atlantic}

The Indian Ocean water introduced into the South Atlantic as part of the warm water route would be carried to the north by the Benguela Current (the warm surface water is driven offshore by the coastal upwelling process). The South Atlantic subtropical gyre is unique in that it receives heat at the poleward eastern corner. The anomalous oceanic heat loss of $10^{\circ} \mathrm{S}$ in the eastern South Atlantic (but west of the Benguela upwelling regime) reported by Bunker [1980] may be a product of the introduction of warm water from the south.

The path of the northward flowing warm water in the Atlantic is presumably incorporated within the large-scale gyre circulation, passing northward in the western limits of the equatorial region and within the western boundary of the North Atlantic. The path across the equator is unclear, as the upper layer return flow is likely to become involved with the active mixing regime and complicated vertical and zonal circulation pattern characteristic of the equatorial zone. Kawase and Sarmiento [1985] show evidence for significant upward flux of nutrients across isopycnal surfaces within the Atlantic equatorial zone induced by mixing processes. Crossequatorial transfer of mass within the upper layer is supported by inverse solution for sets of zonal hydrographic sections across the Atlantic. Roemmich [1983] determines the upper layer northward flux across the equatorial zone accomplished by geostrophic and Ekman transport for the IGY sections at $24^{\circ} \mathrm{S}, 8^{\circ} \mathrm{S}, 8^{\circ} \mathrm{N}$, and $24^{\circ} \mathrm{N}$ as $31.1 \mathrm{~Sv}, 32.7 \mathrm{~Sv}, 5.1 \mathrm{~Sv}$, and 18.6 Sv respectively (from his Figure 3 ).

Molinari et al. [1985] find that the Florida Current average transport from April 1982 to August 1983 is 30.6 Sv. The transport of the Florida Current through the Florida Straits would thus be composed of about $50 \%$ thermohaline and $50 \%$ wind-driven circulation. There is the question of the similarity of this transport to the wind-driven Sverdrup transport function over the interior North Atlantic [Leetmaa et al., 1977], but as was pointed out by Roemmich and Wunsch [1985], the western boundary flow need not match the Sverdrup interior transport, as nonlinear conditions may extend into the interior region.

In summary, it is proposed that the upper layer water flowing northward in the Atlantic Ocean required to feed NADW production is derived primarily from the thermocline and that it is drawn from each ocean, along what is referred to as the warm water route. North Pacific thermocline water enters the Indian Ocean via the Indonesian seas, where strong vertical mixing induces a nearly isohaline condition while carrying heat downward and nutrients upward. The Pacific water, marked by low salinity, is transported across the Indian Ocean within the South Equatorial Current. The excess water introduced to the Indian Ocean by advection through the Indonesian seas is transferred to the Agulhas Current via the Mozambique Channel. The return water becomes saltier during its transit of the Indian Ocean owing to the regional excess evaporation, and in addition its volume flux increases as it incorporates NADW upwelling into the Indian Ocean thermocline. Warm water transfer into the Atlantic is accomplished as a branch of the Agulhas Current enters the South Atlantic rather that curl back to the Indian Ocean as part of the Agulhas retroflection. The introduction of warm water into the poleward eastern corner of the South Atlantic thermocline is responsible for the unique equatorward heat flux of the South Atlantic. Upper layer water is carried to the north in the Atlantic Ocean within the two subtropical gyres. Transfer across the equator is accomplished within the complex vertical and horizontal circulation pattern of the region. The upper layer water is further modified in the Atlantic by excess evaporation, and it incorporates additional NADW.

While additional field work is needed within various sites of the proposed circulation pattern to arrive at better determination of transport values, available information supports the hypothesis that the flow compensating the production and export from the North Atlantic of NADW is accomplished by linkage of the warm water or thermocline layers of the ocean.

The time scale of the circulation pattern is likely to be $O(1000)$ years within the deep water [Broecker and Peng, 1982], but the return flow would represent a shorter time scale, as it is concentrated within the upper layer and along a more confined path. The approximate time for thermocline water to be carried from the central tropical Pacific along the $40,000-\mathrm{km}$-long warm water route to the North Atlantic is only 13 to 130 years, using $0.10-\mathrm{m} / \mathrm{s}$ and $0.01-\mathrm{m} / \mathrm{s}$ characteristic velocity, respectively.

There is increasing evidence that surface water characteristics in the North Atlantic and the rate of NADW production (including its specific characteristics and changes of the relative contribution from each of the major sites) vary on the decadal time scale [Lazier, 1973, 1980; Clarke, 1985; Swift, 1984; Roemmich and Wunsch, 1985]. There is also evidence that deep water geochemical tracers have varied in phase with variations in North Atlantic surface water temperatures on time scales of tens of thousands of years, marking glacialinterglacial oscillations [Ruddiman and McIntyre, 1981; Ruddiman, 1985; Mix and Fairbanks, 1985]. Positive correlation of NADW production rate and North Atlantic surface water temperatures follows from the argument presented by Warren [1983]: the buoyancy removal allowing deep convection is induced in part by high evaporation rates sustained by warm surface water temperatures relative to the atmosphere.

There are many causes for climate variability involving the coupled ocean-atmosphere system with numerous positive and negative feedbacks. The thermohaline circulation cell described in the paper may play some role in that the cell may be weakened, strengthened or in other ways altered, by variations in the wind driven circulation. This would change interocean exchange of thermocline water and hence the global heat and fresh water fluxes and perhaps influencing the production rate of characteristics of NADW. The two inter-ocean links may be vulnerable to change.

\section{The Agulhas Link}

Variation of the Agulhas Current flow into the Atlantic has been discussed by de Ruijter and Boudra [1985] using a winddriven nonlinear barotropic model. While increasing the Rossby number reduces the connection between the subtropical gyres of the two oceans, changes also are forced by altering the wind field: as the zero wind stress curl (maximum westerlies) moves further south of Africa, exchange between the two subtropical gyres increases. Ou and de Ruijter [1985] find that the Agulhas separation from the continental margin becomes less complete (i.e., more water flows into the Atlantic) 
as the Agulhas transport decreases. Thus the presence of strong seasonal variation of the wind stress over the South Atlantic-Indian ocean basin as reported by Hellerman and Rosenstein [1983] (i.e., southward movement of the zero wind stress curl in the summer), may be expected to have an impact on the South Atlantic circulation and climatology.

Van Loon and Rogers [1984] show that much of the seasonal wind variation along $40^{\circ} \mathrm{S}$ is in the second harmonic, with maximum wind at the time of each solstice and with significant interannual variations: weak in 1958 and 1978 and strong in 1957 and 1979 (the four years included in their study). Interannual variations in the south Indian Ocean may be linked to the Southern Oscillation in that the sea level air pressure along the westerlies over the South Indian Ocean shows negative correlation with air pressure at Darwin, which is representative of changes over much of the central and eastern Indian Ocean [Rasmusson, 1985]. As the wind stress curl over the Indian Ocean changes the Agulhas transport and retroflection pattern, its branching into the South Atlantic responds [de Ruijter and Boudra, 1985; Ou and de Ruijter, 1985], affecting the heat/water flux into the South Atlantic.

On the glacial-interglacial scale, variation of the warm water link around the southern tip of Africa may also have occurred. Prell et al. [1980], in their sediment core study of Indian Ocean surface circulation 18,000 years ago (during the height of the last glacial period), found that the position of the subtropical convergence was about $2^{\circ}$ further north than the present position and that the Agulhas Current was composed of cooler water. In this case, less warm Indian Ocean water would flow into the South Atlantic during the glacial periods. This would alter the thermal character of the Atlantic thermocline relative to present conditions, weaking the negative esturary thermohaline circulation cell.

\section{The Indonesian Sea Link}

Another section of the warm water route that may be susceptible to variability is the Pacific to Indian exchange. The tropical Pacific surface water and that within the Indonesian seas represent a large reservoir of heat and relatively fresh water. Its transfer into the Indian Ocean could represent a significant interocean flux of heat and fresh water. The transport of three primary water mass layers across $30^{\circ} \mathrm{S}$ for the world ocean as presented by Stommel [1980] is very large, unreasonably so when compared with residence time estimates. These transport values are significantly altered towards more "acceptable" levels when the Indonesian sea link is included [Piola and Gordon, 1985].

Significant variability of the through flow transports is anticipated on a variety of time scales, including the seasonal cycle forced by the regional monsoon wind system and interannual variations associated with the Southern Oscillation. The presence of strong seasonality is pointed out by Wyrtki [1961], who notes: “...the close interrelation between the [monsoonal-driven] circulation at the surface [including upwelling distribution] and in the depth of the water exchange betwen the Pacific and Indian Ocean...." However, interannual changes in sea level between the Pacific and Indian oceans, which would be a factor in driving the interocean exchange, appear to be small (K. Wyrtki, personal communication, 1985). A relation between sea surface temperature in the Indonesian seas and Southern Oscillation-El Niño events, with a few months' lead of the temperature anomalies, has been reported [Nicholls, 1984]. This relation may be a manifestation of larger-scale variability, as the heat content of the tropical Pacific is observed to gradually increase prior to an El Niño event [Wyrtki, 1985a,b].
Acknowledgments. The concept presented in this paper was the basis of a number of oral presentations during 1985; helpful comments were received from many people, including $K$. Wyrtki, T. Takahashi, G. Reverdin, W. Ruddiman, R. Fairbanks, and B. Huber. The work was supported by the Office of Naval Research contract NOOO14-84-C-0132. Lamont-Doherty Geological Observatory contribution 3962.

\section{REFERENCES}

Banbridge, A. E., GEOSECS Atlantic Expedition, vol. 1., Hydrographic Data, 1972-1973, 121 pp., National Science Foundation. U.S. Government Printing Office, Washington, D. C., 1981.

Bang, N. D., Dynamic interpretations of a detailed surface temperature chart of the Agulhas Current retroflexion and fragmentation area, S. Afr. Geogr. J., 52, 67-76, 1970.

Baumgartner, A., and E. Reichel, The World Water Balance: Mean Annual Global, Continental and Maritime Precipitation, Evaporation and Run-off, 179 pp., Elsevier, New York, 1975.

Broecker, W., A revised estimate for the radiocarbon age of North Atlantic Deep Water, J. Geophys. Res., 84, 3218-3266, 1979.

Broecker, W. S., and T-H. Peng, Tracers in the Sea, 690 pp., LamontDoherty Geological Observatory, Palisades, N. Y., 1982.

Broecker, W. S., T. Takahashi, and T. Li, Hydrography of the Central Atlantic, I, The two-degree discontinuity, Deep Sea Res., 23, 1083$1104,1976$.

Bunker, A. F., Trends of variables and energy fluxes over the Atlantic Ocean from 1948 to 1972, Mon. Weather Rev., 108(6), 720-732. 1980.

Clarke, R. A., Temporal and spatial scales of Labrador Sea water formation, NASA Conf. Publ., 2367, 7-11, 1985.

Coachman, L. K., K. Aagaard, and R. B. Tripp, Bering Strait: The Regional Physical Oceanography, 172 pp., University of Washington Press, 1975.

Cox, M. D., A baroclinic numerical model of the world ocean: Preliminary results, in Numerical Models of Ocean Circulation, 364 pp., National Academy Press, Washington, D. C., 1975.

de Ruijter, W., Asymptotic analysis of the Agulhas Current, Rev. Pure Appl. Geophys., 12, 361-373, 1982.

de Ruijter, W. P. M., and D. B. Boudra, The wind-driven circulation in the South Atlantic-Indian Ocean, I, Numerical experiments in a one-layer model, Deep Sea Res., 32, 557-574, 1985.

Dietrich, G., Veroeff. der Int. Komm. fuer der Meer, 27, p. 1, Univ. of Berlin, German Democratic Republic, 1935.

Duncan, C. P., An eddy in the subtropical convergence southwest of South Africa, J. Geophys. Res., 73(2), 531-534, 1968.

Fine, R. A., Direct evidence using tritium data for throughflow from the Pacific into the Indian Ocean, Nature, 315, 478-480, 1985.

Fu, L., The general circulation and meridional heat transport of the South Atlantic determined by inverse methods, J. Phys. Oceanogr., $11,1171-1193,1981$.

Fu, L., Mass, heat and freshwater fluxes in the south Indian Ocean, $J$. Phys. Oceanogr., in press, 1986.

Georgi, D. T., Modal properties of Antarctic Intermediate Water in the southeast Pacific and the South Atlantic, J. Phys Oceanogr., 9, 456-468, 1979 .

Georgi, D. T., On the relationship between the large-scale property variations and fine structure in the Circumpolar Deep Water, $J$. Geophys. Res., 86, 6556-6566, 1981.

Godfrey, J. S., and T. J. Golding, The Sverdrup relation in the Indian Ocean, and the effect of Pacific-Indian Ocean through flow on Indian Ocean circulation and on the East Australian Current, $J$. Phys. Oceanogr., 11, 771-779, 1981.

Gordon, A. L., Indian-Atlantic transfer of thermocline water at the Agulhas retroflection, Science, 227, 1030-1033, 1985

Gordon, A. L., and C. L. Greengrove, Geostrophic circulation of the Brazil-Falkland confluence, Deep Sea Res., in press, 1986.

Gordon, A., and E. Molinelli, Southern Ocean Atlas: Thermohaline and Chemical Distribution and the Atlas Data Set, 34 pp., 233 plates, Columbıa University Press, New York, 1982.

Gordon, A. L., and A. R. Piola, Atlantic Ocean upper layer salinity budget, J. Phys. Oceanogr., I3, 1293-1300, 1983.

Grundlingh, M. L., On the volume transport of the Agulhas Current, Deep Sea Res., Part A, 27, 557-563, 1980.

Grundlingh, M. L., Occurrence of Red Sea water in the southweste Indian Ocean, 1981, J. Phys. Oceanogr., 15, 207-212, 1984.

Grundlingh, M. L., Features of the northern Agulhas Current in spring, 1983, S. Afr. J. Sci., in press, 1986.

Hall, M. M., and H. L. Bryden, Direct estimates and mechanisms of ocean heat transport, Deep Sea Res., 29, 339-359, 1982. 
Harris, T. F. W., Sources of the Agulhas Current in the spring of 1964, Deep Sea Res., 19, 633-650, 1972.

Harris, T. F. W., and D. Van Foreest, The Agulhas Current in March 1969, Deep Sea Res., 25, 549-561, 1978.

Hastenrath, S., On meridional heat transports in the world ocean, $J$. Phys. Oceanogr., 12, 922-927, 1982.

Hellerman, S., and M. Rosenstein, Normal monthly wind stress over the world ocean with error estimates, J. Phys. Oceanogr., 13, 10931104,1983

Huber, B., D. Camp, W. Haines, S. Rennie, and A. Gordon, Agulhas retroflection cruise, November-December 1982, A data report, Tech. Rep. 85-4, Lamont-Doherty Geol. Observ., Palisades, N. Y., 1985.

Kawase, N., and J. L. Sarmiento, Nutrients in the Atlantic thermocline, J. Geophys. Res., 90, 8961-8979, 1985.

Killworth, P. D., Deep convection in the world ocean, Rev. Geophys. $2 I(1), 1-26,1983$.

Lazier, J. R. N., The renewal of Labrador Sea water, Deep Sea Res., 20, 341-353, 1973.

Lazier, J. R. N., Oceanographic conditions at O. W. S. Bravo, 19641074, Atmos. Ocean., 18, 227-238, 1980.

Leetma, A., P. Niiler, and H. Stommel, Does the Sverdrup relation account for the mid-Atlantic circulation?, J. Mar. Res., 34, 1-10, 1977.

Levitus, S., Climatological atlas of the world ocean, NOAA Prof. Pap. 13, 173 pp., U.S. Government Printing Office, Washington, D. C., 1982.

Lutjeharms, J. R. E., The Agulhas Current system during the northeast monsoon season, J. Phys. Oceanogr., 6, 665-670, 1976.

McCartney, M., Subantarctic Mode Water, in A Voyage of Discovery (Suppl. to Deep Sea Res.), edited by M. Angel, pp. 103-119, Pergamon, New York, 1977.

McCartney, M. S., and L. D. Talley, Warm-to-cold water conversion in the northern Atlantic Ocean, J. Phys. Oceanogr., 14, 922-935, 1984.

Miranda, L. B., and B. M. Castro Filho, Geostrophic flow conditions of the Brazil Current at $19^{\circ} \mathrm{S}$, Cienc. Interam., 22, 44-48, 1981.

Mix, A. C., and R. G. Fairbanks, North Atlantic surface-ocean control of Pleistocene deep-ocean circulation, Earth Planet. Sci. Lett. 73, 231-243, 1985 .

Molinari, R. L.. W. D. Wilson, and K. Leaman, Volume heat transports of the Florida Current: April 1982 through August 1983, Science, 227, 295-297, 1985.

Nicholls, N., The Southern Oscillation and Indonesian sea-surface temperature, Mon. Weather Rev., II2, 424-432, 1984.

Olson, D. B., and R. H. Evans, Rings of the Agulhas Current, Deep Sea Res., in press, 1985.

$\mathrm{Ou}, \mathrm{H}$. W., and W. de Ruijter, Separation of an inertial boundary current from an irregular coastline, $J$. Phys. Oceanogr., in press, 1985.

Pearce, A. F., Some features of the upper $500 \mathrm{~m}$ of the Agulhas Current, J. Mar. Res., 35(4), 731-751, 1977.

Pickard G., and W. Emery, Descriptive Physical Oceanography, 4th ed., 249 pp., Pergamon, New York, 1982.

Piola, A., and D. Georgi, Circumpolar properties of Antarctic Intermediate Water and Subantarctic Mode Water, Deep Sea Res., 29 $687-711,1982$.

Piola, A. R., and A. L. Gordon, Pacific and Indian Ocean upper-layer salinity budget, J. Phys. Oceanogr., 14, 747-753, 1984.

Piola, A., and A. Gordon, Note on oceanic heat and freshwater fluxes at $30^{\circ} \mathrm{S}$, paper presented at the IAMAP/IAPSO Joint Assembly, Int. Assoc. of Meteorol. and Atmos. Phys./Int. Assoc. for Phys. Sci. of the Oceans, Honolulu, Hawaii, Aug. 5-6, 1985

Prell, W., W. Hutson, D. Williams, A. Bé, K. Geitzenauer, and B. Molfino, Surface circulation of the Indian Ocean during the last glacial maxımum, approximately 18,000 yr. B.P., Quat. Res., 14, 309-336, 1980.

Rasmusson, E., El Niño and variations in clımate, Amer. Scient., 73 , $168-177,1985$.

Reid, J. L., Jr., On the temperature, salinity and density differences between the Atlantic and Pacific oceans in the upper kilometre, Deep Sea Res., 7, 265-275, 1961.

Reid, J., and R. Lynn, On the influence of the Norwegian-Greenland and Weddell Seas upon the bottom waters of the Indian and Pacific oceans, Deep Sea Res., 18, 1063-1088, 1971.

Rochford, D., Distribution of Banda Intermediate Water in the Indian Ocean, Aust. J. Mar. Freshwater Res., 17, 61-76, 1966.

Roemmich, D. Estimation of meridional heat flux in the North Atlantic by inverse methods, J. Phys. Oceanogr., I0, 1972-1983, 1980.

Roemmich, D., The balance of geostrophic and Ekman tansports in the tropical Atlantic Ocean, J. Phys. Oceanogr., 13, 1534-1539, 1983.

Roemmich, D., and C. Wunsch, Two transatlantic sections: Meridional circulation and heat flux in the subtropical North Atlantic Ocean, Deep Sea Res., 32, 619-664, 1985.

Ruddiman, W. F., Quarternary North Atlantic surface paleoceanography in regions of potential deep-water formation, NASA Conf. Publ., 2367, 28-31, 1985.

Ruddiman, W. F., and A. McIntyre, The North Atlantic ocean during the late deglaciation, Palaeogeogr., Palaeoclimatol., Palaeoecol., 35, $145-214,1981$.

Ruddiman, W. F., and A. McIntyre, Ice-age thermal response and climatic role of the surface Atlantic Ocean, $40^{\circ} \mathrm{N}$ to $63^{\circ} \mathrm{N}$, Geol Soc. Am. Bull., 95, 381-396, 1984.

Saetre, R., and A. J. da Silva, The circulation of the Mozambique Channel, Deep Sea Res., 31, 485-508, 1984.

Spencer, D., W. Broecker, H. Craig, and R. Weiss, GEOSECS Indian Ocean Expedition, 140 pp., U.S. Government Printing Office, Washington, D. C., 1982.

Stommel, H., A survey of ocean current theory, Deep Sea Res., 4, $149-184,1957$.

Stommel, H., Asymmetry of interoceanic fresh-water and heat fluxes, Proc. Natl. Acad. Sci. U.S.A., 77, 2377-2381, 1980.

Stommel, H., and A. Arons, On the abyssal circulation of the world ocean, I, Stationary planetary thru patterns on a sphere, Deep Sea Res., 6(2), 140-154, 1960.

Swift, J. H., A recent $T-S$ shift in the deep water of the northern North Atlantic, in Climate Processes and Climate Sensitivity, Geophys. Monogr. Ser., vol 29, edited by J. E. Hansen and T. Takahashi, pp. 39-47, AGU, Washington, D. C., 1984.

Talley, L. D., Meridional heat transport in the Pacific Ocean, J. Phys. Oceanogr., 14(2), 231-241, 1984.

Toole, J., and M. Raymer, Heat and fresh water budgets of the Indian Ocean-revisited, Deep Sea Res., 32, 917-928, 1985.

Tsuchiya, M., Upper Waters of the Intertropical Pacific Ocean, Johns Hopkins Oceanogr. Ser. 4, 50 pp., Johns Hopkins Univ., Baltimore, Md., 1968.

Van Loon, H., and J. C. Rogers, Interannual variations in the halfyearly cycle of pressure gradients and zonal wind at sea level in the southern hemisphere, Tellus, 36A, 76-86, 1983.

Veronis, G., Model of world ocean circulation, I, Wind-driven, two layer, J. Mar. Res., 31, 228-288, 1973.

Warren, B. A., Deep circulation of the world ocean, in Evolution of Physical Oceanography, Scientific Surveys in Honor of Henry Stommel, edited by B. A. Warren and C. Wunsch, pp. 6-41, MIT Press, Cambridge, Mass., 1981.

Warren, B. A., Why is no deep water formed in the North Pacific? $J$. Mar. Res., 41, 327-347, 1983.

Worthington, L. V., The water masses of the world ocean: Some results of a fine-scale census, in Evolution of Physical Oceanography, Sclentific Surveys in Honor of Henry Stommel, edited by B. A. Warren and C. Wunsch, pp. 42-69, MIT Press, Cambridge, Mass., 1981.

Wunsch, C., An eclectic Atlantic ocean circulation model, 1, The meridional flux of heat, J. Phys. Oceanogr., 14, 1712-1733, 1984.

Wyrtki, K., The water exchange between the Pacific and the Indian Ocean in relation to upwelling processes, in Proc. Pac. Sci. Congr. $9 t h, 16,61-66,1957$

Wyrtki, K., Physical oceanography of the Southeast Asian waters, Scientific Results of Maritime Investigations of the South China Sea and Gulf of Thailand 1959-1961, NAGA Rep. 2, 195 pp. Scripps Inst. of Oceanor., La Jolla, Calif., 1961.

Wyrtki, K., Oceanographic Atlas of the International Indian Ocean Expedition, 531 pp., National Science Foundation, Washington, D. C., 1971

Wyrtki, K., Water displacements in the equatorial Pacific during the 1982-83 El Niño, paper presented at the abs. IAMAP-IAPSO Joint Assembly, Int. Assoc. of Meteorol. and Atmos. Phys./Int. Assoc. for Phys. Sci. of the Oceans, Honolulu, Hawaii, Aug. 5-16, $1985 a$.

Wyrtki, K., Water displacements in the Pacific and the genesis of El Niño cycles, J. Geophys. Res., 90(C4), 7129-7132, 1985 b.

Wyrtki, K., and B. Kilonsky, Mean water current structure during the Hawaii-to-Tahiti shuttle experiment, J. Phys. Oceanogr., 14(2), 242$254,1984$.

A. L. Gordon, Lamont-Doherty Geological Observatory of Columbia University, Palisades, NY 10964.

(Received November 11, 1985 accepted January 10, 1986.) 